\title{
Serum Immunoglobulin E Concentrations and Radioallergosorbent Tests in Children with Atopic Dermatitis
}

\author{
JOSEPH A. CHURCH, DENNIS G. KLEBAN, AND JOSEPH A. BELLANTI ${ }^{(20)}$ \\ Departments of Pediatrics and Microbiology, Georgetown University Medical Center, Washington, D.C., USA
}

\begin{abstract}
Extract
Serum IgE concentrations and the presence of allergen-specific IgE were determined in a series of 23 children with atopic dermatitis. In this group $83 \%$ had significantly elevated serum levels of IgE, $91 \%$ had coexistent respiratory allergy, $70 \%$ had radioallergosorbent test (RAST) evidence of pollen hypersensitivity, and $43 \%$ gave a history and demonstrated a RAST score consistent with milk or egg hypersensitivity. In patients with eczema a significant proportion of the elevated serum IgE appears to be antigen specific.

\section{Speculation}

The mechanisms involved in the pathogenesis of atopic dermatitis remain unknown. Elevated serum IgE and the presence of antigen specific IgE suggest a causal relationship of atopic eczema with immediate hypersensitivity. Alternatively, the disease process may have a marked stimulatory effect on the specific IgE response. The precise nature of this association remains to be determined.
\end{abstract}

Atopic dermatitis or eczema has been defined as an allergic dermatosis which is characterized by erythema, intense itching, and vesiculation (3). Although the pathogenesis is unknown, the strong association of atopic dermatitis, asthma, hay fever, and family history of atopic disease suggests that immunologic mechanisms are frequently involved. Elevated serum IgE levels have been reported frequently in atopic dermatitis, $(1,6-8,10)$ and the concentration of IgE appears to be correlated with the severity of the dermatitis $(6,7)$. Further, Hoffman et al. $(5,6)$ have recently demonstrated specific IgE to a wide variety of antigen in patients with eczema.

The present study was undertaken to evaluate serum IgE levels in a selected group of pediatric patients seen in an allergy clinic to determine the presence or absence of allergen-specific IgE and to examine the relation of atopic dermatitis to inhalant and food allergies.

\section{SUBJECTS AND METHODS}

\section{PATIENT POPULATION}

The patient population consisted of 23 children ranging in age from 1 to 15 years with varying degrees of symptomatic atopic dermatitis seen at the Georgetown University Allergy-Immunology-Respiratory Disease (AIR) Clinic (Table 1). There were 10 males and 13 females in the study group. In order to examine the relationships of age and $\mathrm{IgE}$, the patients were divided into four age categories: 9 were 1-4 years of age, 4 were 5-8 years of age, 6 were $9-12$ years of age, and 4 were 13-15 years of age.

\section{CLASSIFICATION OF DISEASE}

Atopic dermatitis was classified as mild, moderate, or severe àccording to the extent of the eruption at the time serum samples were obtained. Dermatitis of limited distribution with few or no active lesions was classified as "mild." Dermatitis limited to the face, neck, or flexor surfaces of the extremities with limited erythema and vesiculation was "moderate." Extensive involvement of the trunk and extensor surfaces, severe lichenification, extensive erythema, and vesiculation or any of these in combination were classified as "severe."

For the purpose of this study, allergic rhinitis or asthma was designated as present $(+)$ or absent $(-)$ (Table 1). The diagnosis of respiratiory allergy was made by standard allergic diagnostic procedures (14). A history of food allergy to milk or egg was considered positive $(+)$ if parents observed worsening of the eruption coincident with intake of these foods on at least two separate occasions.

\section{SERUM IgE CONCENTRATIONS}

Serum IgE concentrations were determined using the solid phase radioimmunoassay Phadebas IgE Test (16). For improved accuracy at high concentrations, levels measuring over $3,000 \mathrm{U} / \mathrm{ml}$ in initial specimens were appropriately diluted until concentrations were achieved within the more accurate range of measurement of the test $(10-3,000 \mathrm{U} / \mathrm{ml})$. Although normal limits for serum $\operatorname{IgE}$ concentrations have not been definitively established (2), recent reports suggest an upper limit of $435 \mathrm{U} / \mathrm{ml}$ for the normal adult (6). More recently, age-related serum IgE concentrations have been reported in children $1-15$ years of age (2).

\section{RADIOALLERGOSORBENT TEST}

The radioallergosorbent test was performed by the method provided in the Phadebas-RAST (16) kit, which is a modification of the technique originally described by Wide et al. (15). Specific allergens covalently coupled to paper discs were incubated with $0.05 \mathrm{ml}$ patients' sera for $3 \mathrm{hr}$, washed three times with $0.15 \mathrm{M} \mathrm{NaCl}$, and incubated for $18 \mathrm{hr}$ with $0.05 \mathrm{ml}$ ${ }^{125}$ I-anti-IgE. After further washing in $0.15 \mathrm{M} \mathrm{NaCl}$, the discs were placed in plastic tubes $(16 \times 125 \mathrm{~mm}(17))$, and the radioactivity bound to the discs was determined in a Nuclear Chicago Ultrascaler II gamma counter. Disintegrations per minute were compared with standard controls according to the method of Hoffman and Haddad (4). In this procedure, the nonspecific binding of ${ }^{125} \mathrm{I}$-anti-IgE was determined for each type of allergen disc without prior incubation with serum. Values less than 1.4 times this nonspecific binding were considered negative reactions; values 1.4-1.7 times the nonspecific binding were considered borderline reactions; and values greater than 1.7 times the nonspecific binding were considered positive reactions. In addition to these negative controls, positive control sera for each antigen were included in each RAST procedure. In our laboratory, this method of calculation provides a more sensitive assay in determining food-specific IgE antibody, and an equivalent degree of sensitivity for inhalent-specific IgE as to that obtained with commercially available standards. 
Table 1. Clinical findings, IgE concentrations, radioallergosorbent tests $(R A S T)$, and skin tests in patients with atopic dermatitis classified according to severity of skin eruption

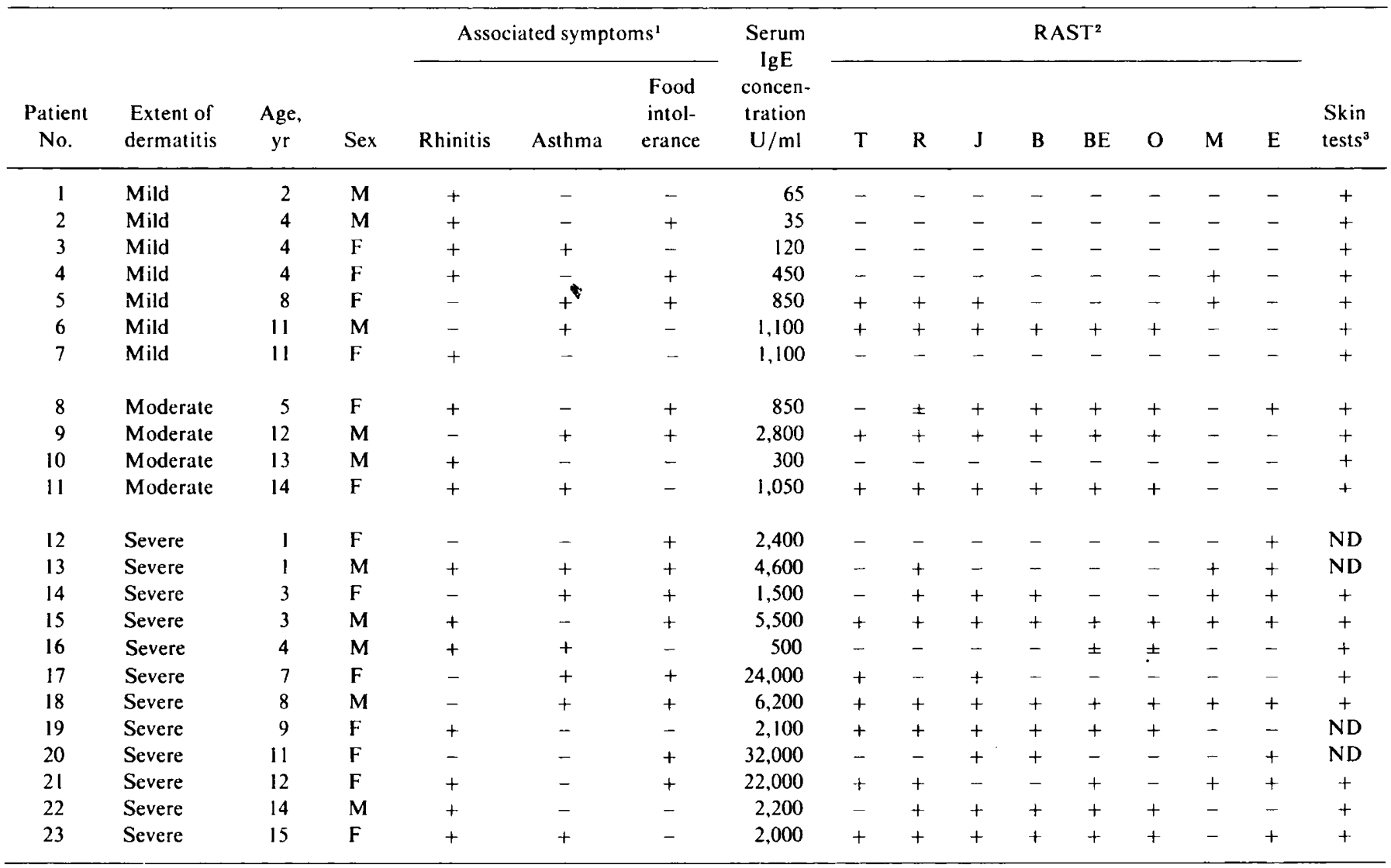

${ }^{1}$ Rhinitis, asthma, and history of food intolerance are designated as present $(+)$ or absent $(-)$ (see text).

${ }^{2}$ Individual RAST scores are reported for each of the following allergens respectively: timothy $(T)$, ragweed $(R)$, june grass $(J)$, bermuda grass $(B)$, box elder (BE), white oak $(O)$, milk (M), and egg $(E)$.

${ }^{3}$ Skin test positivity for dust, molds, or weeds other than ragweed is designated as present $(+)$, absent $(-)$, or not done (ND).

\section{SKIN TESTING}

Skin tests for immediate hypersensitivity were performed with extracts (18) of dust, and a variety of molds, grasses, trees, and weeds. Scratch tests with 20,000 P.N.U./ml were performed initially, and if negative, were followed by intradermal tests employing $0.03 \mathrm{ml}$ extract at protein concentrations of 1,000 P.N.U./ml. Tests were considered positive if a wheal of greater than $7 \mathrm{~mm}$ in diameter was elicited with concomitant negative control tests.

\section{RESULTS}

\section{CLINICAI. FINDINGS}

Clinical data and results of serum IgE determinations, radioallergosorbent test, and skin tests are presented in Table 1. Seven patients $(30 \%)$ were classified as having mild disease, 4 patients (17\%) moderate involvement, and $12(52 \%)$ severe disease. Twenty-one patients $(91 \%)$ had upper or lower respiratory allergy diagnosed clinically, and $13(57 \%)$ had histories of milk or egg hypersensitivity. Immediate hypersensitivity skin testing for a complete series of antigens was performed on fewer than half of the patients at the time of this report.

\section{SERUM IgE CONCENTRATIONS}

Elevated serum IgE levels (greater than $435 \mathrm{U} / \mathrm{ml}$ ) were detected in $83 \%$ of the total patient population. Tables 2 and 3 demonstrate the age and sex distribution of our patients and the
Table 2. Relation between age and elevated levels of serum IgE

\begin{tabular}{cccc}
$\begin{array}{c}\text { Age } \\
\text { group, } \\
\text { yr }\end{array}$ & $\begin{array}{c}\text { No. of } \\
\text { patients }\end{array}$ & $\begin{array}{c}\text { No.with } \\
\text { elevated } \\
\text { IgE }\end{array}$ & $\begin{array}{c}\text { \% with } \\
\text { elevated } \\
\text { IgE }\end{array}$ \\
\hline $1-4$ & 9 & 6 & 67 \\
58 & 4 & 4 & 100 \\
912 & 6 & 6 & 100 \\
1315 & $\frac{4}{23}$ & $\frac{3}{19}$ & 75 \\
Total & & 19 & 83 \\
\hline
\end{tabular}

Table 3. Relation between sex and elevated levels of serum $\operatorname{IgE}$

\begin{tabular}{lccc}
\hline Sex & $\begin{array}{c}\text { No. of } \\
\text { patients }\end{array}$ & $\begin{array}{c}\text { No. with } \\
\text { elevated } \\
\operatorname{lgE}\end{array}$ & $\begin{array}{c}\text { \% with } \\
\text { elevated } \\
\text { IgE }\end{array}$ \\
\hline Male & 10 & 7 & 70 \\
Female & 13 & 12 & 92 \\
\hline
\end{tabular}

relations of these to elevated IgE. It can be seen from these data that the occurrence of elevated IgE is independent of age and sex.

The relationship of serum $\mathrm{IgE}$ and clinical severity is shown in Table 4 and Figure 1. As can be seen from these data, a direct correlation exists between these events $(r=0.7165, P<0.01)$. 


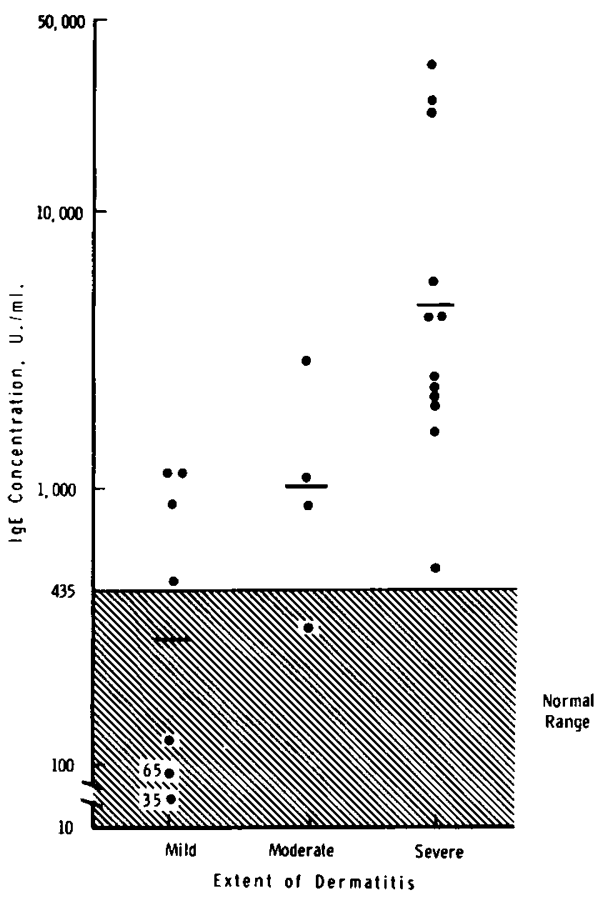

Fig. 1. Relation of serum IgE concentrations to clinical severity of atopic eczema. The normal adult values of serum $\operatorname{IgE}$ globulins are indicated by the shaded area; horizontal bars are the geometric mean values of serum IgE concentrations in each group.

Table 4. Relation between extent of active dermatitis and elevated levels of $\lg E$

\begin{tabular}{lccc}
\hline $\begin{array}{c}\text { Extent of } \\
\text { dermatitis }\end{array}$ & $\begin{array}{c}\text { No. of } \\
\text { patients }\end{array}$ & $\begin{array}{c}\text { No.with } \\
\text { elevated } \\
\text { IgE }\end{array}$ & $\begin{array}{c}\text { \% with } \\
\text { elevated } \\
\text { IgE }\end{array}$ \\
\hline Mild & 7 & 4 & 57 \\
Moderate & 4 & 3 & 75 \\
Severe & 12 & 12 & 100 \\
\hline
\end{tabular}

\section{DISCUSSION}

An elevated serum IgE concentration in $83 \%$ of our patients confirms the studies of others $(3,5-9)$, who report an increased frequency of elevated serum IgE in patients with atopic dermatitis. However, this frequency of elevated $\operatorname{IgE}$ is higher than that described previously (7). This can be a reflection of patient selection since in the present studies the clinical material was drawn exclusively from an allergy clinic where moderate and severe skin disease is prevalent $(70 \%)$, and where the frequency of respiratory allergy is high $(91 \%)$. Similar results were obtained in a recent study by Hoffman et al. (6). An alternative explanation to these findings is that atopic dermatitis may be a manifestation of more than one pathogenetic mechanism.

The use of radioallergosorbent tests was helpful in defining both inhalant and food allergy in the present study and in that of Hoffman et al (6). Because the skin in atopic dermatitis is physiologically abnormal (9), the efficacy of skin testing for allergen identification has been questioned (12). Further, skin testing for food allergy in nondermatitis patients is fraught with difficulty (13), thus making interpretation of these tests in patients with eczema even less useful. In recent studies, Ohman and Johannson (11) further document these difficulties by describing interesting discrepancies between skin test results and antigen- specific serum IgE, especially with regard to food antigens. The availability of RAST as used in the present studies has offered another approach to these problems by providing a simple, accurate, in vitro measurement of reaginic hypersensitivity $(6,15)$. RAST assays for dust and dust mite antigens are less reliable than those for pollen antigens (5). Until more reliable radioallergosorbent tests become commercially available for the more troublesome allergens (e.g., dust, molds, and other foods), specific allergen identification in patients with severe eczema will be based upon less objective criteria.

Perhaps the most controversial aspect of atopic dermatitis is its pathogenesis. The availability of RAST may offer new insights into the multiple mechanism(s) which may be operative in this disease. Although it has been suggested that IgE-mediated reactions are not responsible for the eruption in eczema (12), the demonstration of multiple antigen-specific $\mathrm{IgE}$ indicates that the process involved has a profound effect on the development of specific sensitization. Further elucidation of this pathogenetic process may have immediate and long term diagnostic and therapeutic implications.

\section{SUMMARY}

In the clinical setting of an allergy clinic, atopic dermatitis is frequently associated with respiratory allergies and elevated serum IgE concentrations. The extent of this hyperimmunoglobulinemia E can be directly correlated with the clinical severity of the eruption. Furthermore, a significant proportion of the serum $\operatorname{lgE}$ appears to be antigen-specific.

\section{REFERENCES AND NOTES}

1. Durevitch, A. W., Heiner, D. C., and Reisner, R. M.: IgE in atopic dermatitis and other common dermatoses. Arch. Dermatol, 107: 712 (1973).

2. Gerrard, J. W., Horne, S., Vickers, P., MacKenzie, J. W. A., Goluboff, N. Garson, J. Z., and Maningas, C. S.: Serum IgE levels in parents and children. J. Pediat., 85: 660 (1974)

3. Guiang, S. F., and Speer, F.: Allergic eczema. In F. Speer and R. J. Dockhorn Allergy and Immunology in Childhood, p. 540 (Charles C Thomas, Springfield, III. 1973).

4. Hoffman, D. R., and Haddad, Z. H.: Diagnosis of IgE-mediated reactions to food antigens by radioimmunoassay. J. Allerg. Clin. Immunol., 54: 165 (1974).

5. Hoffman, D. R., and Haddad, Z. H.: Diagnosis of multiple inhalant allergies in children by radioimmunoassay. Pediatrics, 54: 151 (1974).

6. Hoffman, D. R., et al.: Specific lgE antibodies in atopic eczema. J. Allergy Clin. Immunol.. 55: 256 (1975).

7. Johnson, E. E., Irons, J. S., Patterson, R., and Roberts, M.: Serum IgE concentration in atopic dermatitis. J. Allerg. Clin. Immunol.. 54: 94 (1974).

8. Juhlin, L., Johansson, S. G. O., Bennich, H.. Hogman, C.. and Thyresson, N. Immunoglobulin $\mathrm{E}$ in dermatoses. Arch. Dermatol., 100: 12 (1969).

9. Kierland, R. R.: Vascular reactions of the skin in eczema. J. Pediat., 66: 203 (1965)

10. Ogawa, M., Berger, P. A., McIntyre, O. R., Clendenning, W. E., Tomioka, H. and Ishizaka. K.: IgE in atopic dermatitis. Clin. Res., 18: 350 (1970).

11. Ohman, S., and Johansson, S. G. O.: Allergen-specific IgE in atopic dermatitis Acta Dermatovener (Stockholm), 54: 283 (1974).

12. Rostenberg, A.. and Solomon, L. M.: Atopic dermatitis and infantile eczema. In M. Samter: Immunologic Diseases, p. 920 (Little. Brown and Company. Boston, 1971).

13. Tapay, N. J.: Diagnostic tests for allergy. In: F. Speer and R. J. Dockhorn Allergy and Immunology in Childhood, p. 358 (Charles C Thomas. Springfield, III., 1973).

14. Tennenbaum, J. I.: Allergic rhinitis. In: R. Patterson: Allergic Diseases, Diagnosis and Management, p. 161 (J. B. Lippencott, Philadelphia, 1972).

15. Wide, L., Bennich, H., and Johansson, S. G. O.: Diagnosis of allergy by an in vitro test for allergen antibodies. Lancet, ii: 1105 (1967).

16. Pharmacia Laboratories, Inc., Piscataway, N. J.

17. Amersham-Searle, Arlington Heights, III

18. Hollister-Stier Laboratories, Spokane, Wash.

19. The authors wish to thank Dr. Nicholas Giorgio (Pharmacia) for his generous technologic and material support during the course of these studies.

20. Requests for reprints should be addressed to: J. A. Bellanti, M.D.. Georgetown University Medical Center, Gorman Building, Rm. 130, 3800 Reservoir Road. N.W. Washington, D. C. 20007 (USA).

21. Accepted for publication September 29, 1975. 